\title{
Investigation of the Geology and Hydrology of the Mogollon Highlands of Central Arizona: A Project of the Arizona Rural Watershed Initiative
}

$T_{\text {he Mogollon Highlands of east }}$ central Arizona is a region of forested plateau and mountains, deep, sheerwalled canyons, and desert valleys. Known for its scenic beauty and characterized by a generally mild climate, the area, though still sparsely populated, attracts an increasing number of tourists and summer residents. Furthermore, the permanent population is expected to nearly double over the next 50 years. Consequently, there is increased pressure on the water resources of this area for several sometimes conflicting uses. Rational management of water resources is necessary to meet increased domestic requirements while ensuring an adequate supply of water for commercial and agricultural use, for Indian lands, and for preservation of valued environmental elements, including surface waters, riparian woodlands, forest and grassland areas, and wildlife and aquatic habitat. Such management requires an understanding of the relations among different components of the hydrologic system-recharge areas, surface flows, shallow aquifers, deep aquifers, discharge areas, and the regional ground-water flow system - and how each is affected by geology, climate, topography, and human use.

The U.S. Geological Survey (USGS) is conducting an assessment of the hydrogeology of the Mogollon Highlands in cooperation with the Arizona Department of Water Resources. The study, funded through the State's Rural Watershed Initiative program, is one of three assessments being conducted by the USGS. Assessments also are underway in the Upper-Middle Verde River watershed and on the Coconino Plateau. Each study has as its objectives: (1) the collection, compilation, and evaluation of all existing geologic, hydrologic, and related data pertaining to the study area and the creation of a data base that is readily accessible to the public and (2) developing an understanding of the hydrogeologic framework, which is the relation between geologic and hydrologic properties, that can be used for waterresources management purposes and that will support the development of an interpretive and predictive model to estimate the effects of climate and water use on the sustainability of regional water resources.

Although the three continguous areas in north-central Arizona are being studied separately, a single data base is being constructed from which data on each area can be extracted separately.
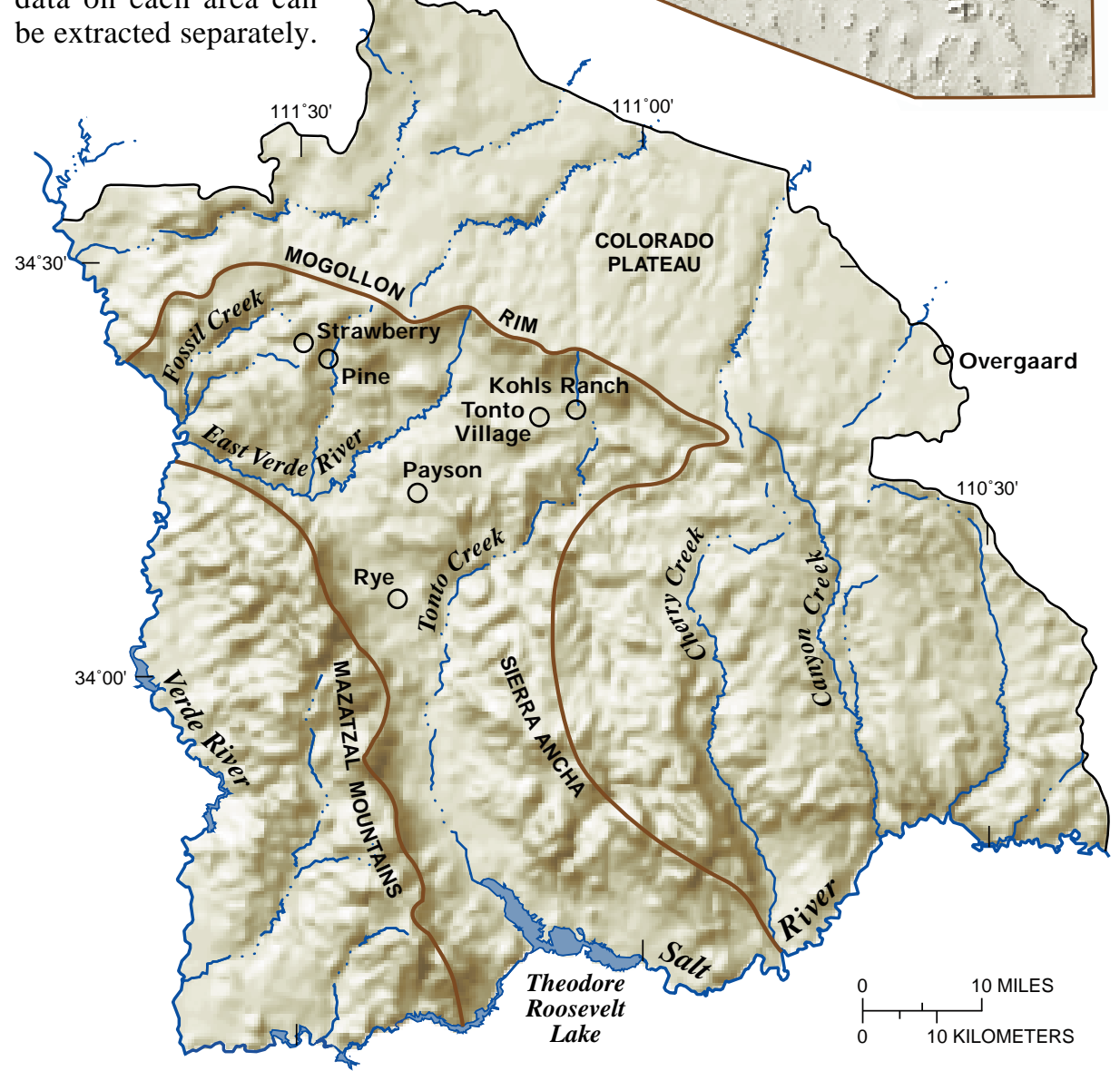

Figure 1. Location of Mogollon Highlands study area. The dark brown line delineates the primary study area; the more extensive area of light-brown tones delineates the proposed boundaries for regional ground-water flow modeling. 


\section{Physical Setting}

The extended study area encompasses about $4,855 \mathrm{mi}^{2}$ (fig. 1), and the main area of focus includes the Fossil Creek, East Verde River, and Tonto Creek Basins below the Mogollon Rim. The Mogollon Rim is the eroded and dissected southwestern edge of the Colorado Plateau and is one of the most striking physical features in the study area; it trends mainly east-west for about 80 miles, forming a steep escarpment about 2,000 ft above a lower, stepped plateau. South of the Mogollon Rim, the Transition Zone, an area of mountain ranges and valleys, separates the Colorado Plateau from the Basin and Range province. Altitudes within the study area range from more than $7,500 \mathrm{ft}$ at the top of the Mogollon Rim to about $1,500 \mathrm{ft}$ at the mouth of the Verde River. Precipitation ranges from more than 30 in. at the higher elevations to about 15 in. annually at the lowest desert locations. Above about 5,000 ft, vegetation is primarily Ponderosa pine forest with piñon pine and juniper woodland, oak woodland, and Sonoran desert vegetation at successively lower altitudes. Population of the study area is approximately 21,000 , about two thirds of which live in the town of Payson. According to the Arizona State Land Department, about 80 percent of the land is owned by the Federal government, primarily within the Tonto National Forest, and about 15 percent of the land is included within five Indian reservations. Only 2.4 percent of the land within the study area is privately owned.

\section{Geology}

The edge of the Mogollon Rim exposes a sequence, nearly $3,000 \mathrm{ft}$ thick, of Paleozoic sedimentary rocks that are capped by Tertiary volcanic rocks in the western part of the study area (fig. 2). The Paleozoic section is underlain by Precambrian rocks including the Mazatzal Quartzite and the Payson granite. The Payson granite forms a topographic bench along the base of the rim that extends for about 10 miles west to east. The town of Payson sits upon this exposure of granite. South of Payson, the Mazatzal Mountains and Sierra Ancha consist largely of Precambrian sedimentary, volcanic, and metamorphic rocks. The two mountain ranges flank the valley of Tonto Creek, which is filled with alluvium of Quaternary and Tertiary age to a depth of about $5,000 \mathrm{ft}$
(Wilson and others, 1959; Feth and Hem, 1963; Mayer, 1978; Richards, 1987; Weisman and Weir, 1990; Weir and Beard, 1997).

The most significant structural characteristics include the shallow northeastward dip of the Paleozoic rocks; the extensive fracturing of sedimentary and granitic rocks; solution features, such as caverns, in carbonate rocks; and northwest-southeast trending extensional faults associated with Basin and Range deformation. The Diamond Rim Fault, which forms a secondary escarpment generally less than 1,000 ft high below the main escarpment of the Mogollon Rim east of Payson, is the largest and most continuous of the northwest-southeast trending extensional faults.

\section{Hydrology}

Perennial surface-water flows are the result of ground-water discharge and are restricted mainly to the major streams of Fossil Creek, the East Verde River, and Tonto Creek plus a few of their larger tributaries. Other streams are intermittent or ephemeral.

The ground-water system consists of several components including multiple aquifers within the sedimentary rocks of the Mogollon Rim, water-bearing zones

,

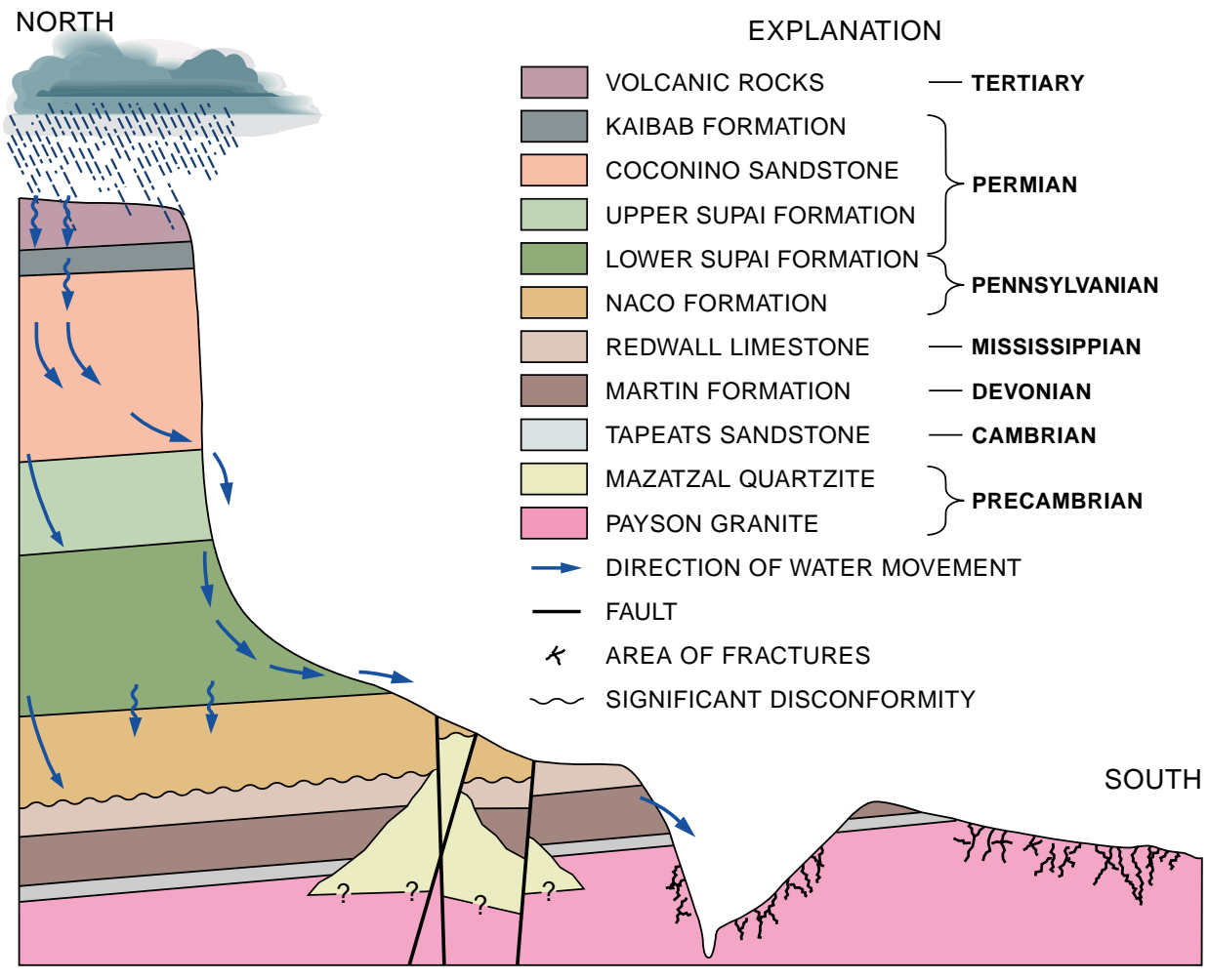

Figure 2. Schematic diagram of geology of the study area showing a generalized north to south cross section from the crest of the Mogollon Rim to the granitic terrain around the town of Payson. Springs may be fed directly from recharge areas on top of the Mogollon Rim or may be fed from deeper ground-water systems.

within fractured parts of the Payson granite, and alluvial aquifers in the basin fill of the Tonto Creek Basin and along some streams. Some springs discharge from the Precambrian rocks of the Sierra Ancha and Mazatzal Mountains, but the hydrologic characteristics of those rocks are not well known. The aquifers within the sedimentary rocks are recharged from precipitation falling on the southern edge of the Colorado Plateau. Permeability within the sedimentary rocks generally is the result of fracturing, jointing, and faulting of rocks of otherwise low permeability. Within carbonate rocks, permeability can be increased by the formation of solution features, such as conduits and caverns, by widening of joints and fractures, and by dissolution of beds. The cap rocks of the Mogollon Rim, which can be Tertiary basalt, and limestone or sandstone of the Kaibab Formation and Coconino Sandstone, generally are highly fractured and permit rapid infiltration of surface waters to lower layers. Waters infiltrating the sedimentary rocks frequently discharge at springs on the face of the Mogollon Rim and along canyon walls and stream channels particularly where permeable rocks overlie less permeable rocks or where fractures or faults force ground-water flow to the surface (Feth and Hem, 1963).

\section{EXPLANATION}

DIRECTION OF WATER MOVEMENT

AREA OF FRACTURES

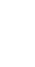




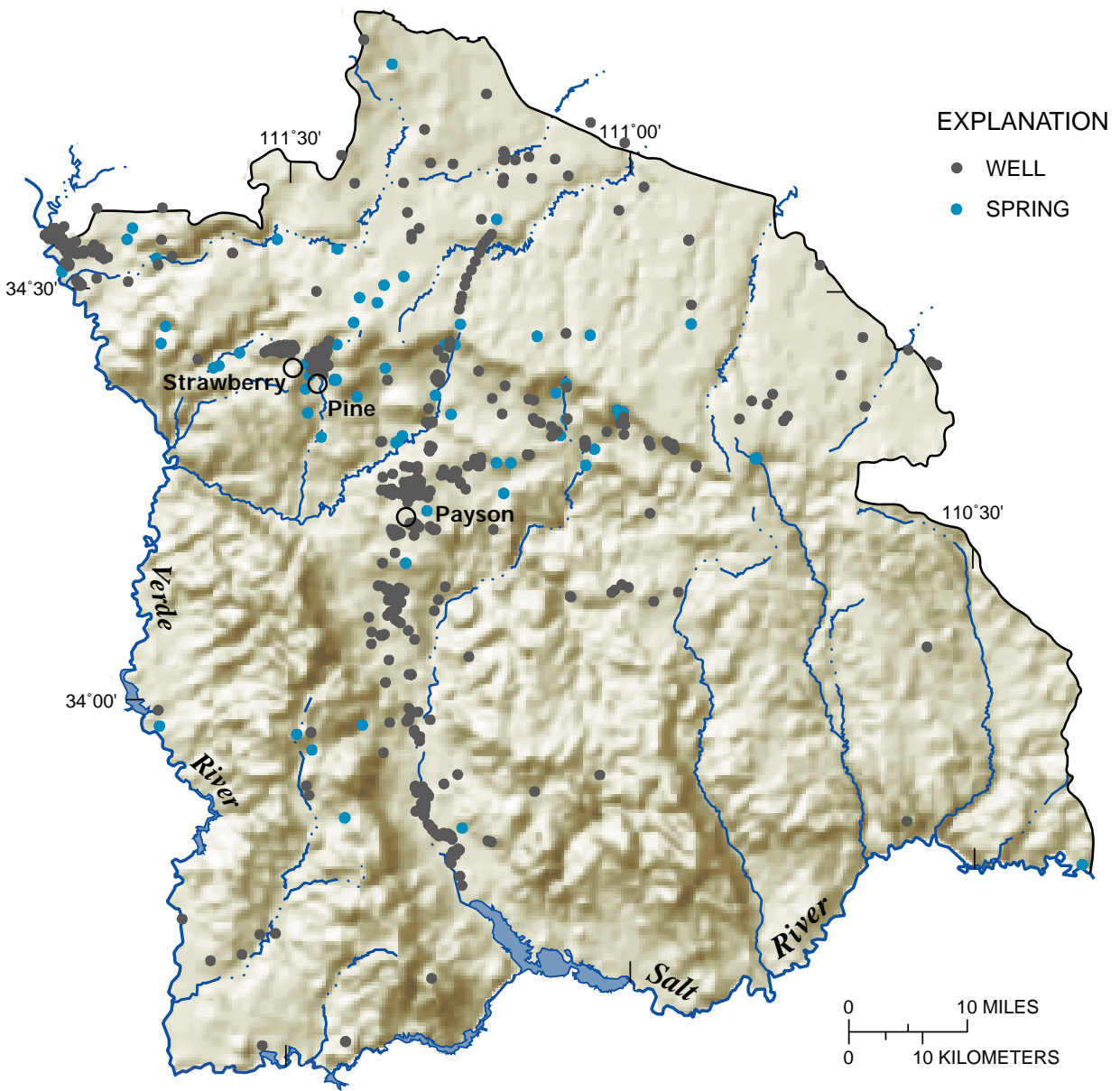

Figure 3. Locations of wells and springs in the study area.

Although the Coconino Sandstone is an important aquifer elsewhere on the Colorado Plateau, most communities within the study area obtain water for domestic use from lower-lying formations, particularly the Supai and Naco Formations. The lower Paleozoic formations, including the Redwall Limestone and Martin Formation, are productive aquifers elsewhere as indicated by spring discharge in several streams, but they have not been developed significantly in the study area. The town of Payson obtains its water from wells in the Payson granite. The location of water within granitic rocks of the study area is dependent on the degree of weathering, fracturing, jointing, and faulting in the rocks because unweathered, unfractured granitic rocks have extremely low primary porosity (Southwest Groundwater Consultants, Inc., 1998). A survey of the USGS National Water Information System (NWIS) ground-water data base shows approximately 1,200 wells in the study area (fig. 3). Most wells in the northern half of the study area are in bedrock aquifers; in the southern part of the Tonto Creek Basin, most wells are in valley fill alluvium. Average depth to from an average of $900 \mathrm{gal} / \mathrm{min}$ in the southern part of the study area to 52 gal/min on the Mogollon Rim and 48 gal/min on the Colorado Plateau. The NWIS contains about 123 springs that are within the study area, mainly on the face of the Mogollon Rim and in the canyons of major tributaries (fig. 3). Discharges range from 0.05 to 18,620 $\mathrm{gal} / \mathrm{min}$ (fig. 4).

\section{Water Use}

Ground water is the source of almost all water for human uses except recreation in the study area. Surface water generally cannot be used because water rights to surface flows are owned by users downstream. About 30 water companies deliver almost 3,500 acre feet of water per year to commercial and domestic customers in the area. There are few irrigated lands in the study area. The town of Payson accounts for about half of the region's water use. On the basis of population projections, water use by the year 2050 could range from about 6,500 to more than 7,600 acre-feet per year. None of the communities within the study area, however, have an adequate 100-year water supply, according to the Arizona Department of Water Resources. Some wells within the study area go dry during periods of drought. Restrictions on domestic water use are frequently imposed in several communities during dry spells. Some wells have shown a decline in water levels in recent years but it is not known if this reflects a regional trend or is instead related to climatic variability and local hydrologic factors.

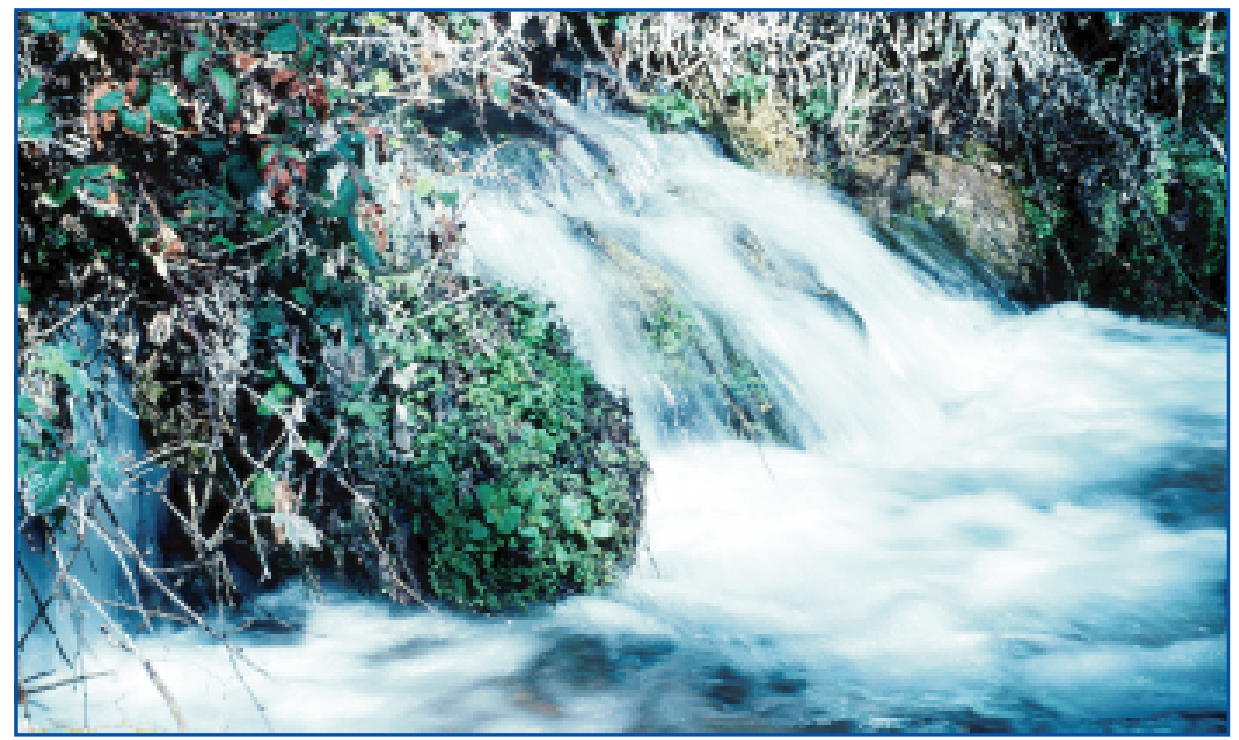

Figure 4. A spring discharging into Fossil Creek. 
Table 1. Values for selected water chemistry properties in Mogollon Highlands

[ $\mathbf{S} / \mathbf{c m}$, microsiemens per centimeter; $\mathbf{m g} / \mathbf{L}$, milligrams per liter; $\mathbf{N}$, number of analyses; $\mathbf{R}$, range; Mn, mean; Md, median]

\begin{tabular}{|c|c|c|c|c|c|c|c|c|c|c|c|c|c|c|c|}
\hline \multirow[t]{2}{*}{$\begin{array}{l}\text { Water } \\
\text { source }\end{array}$} & \multicolumn{3}{|c|}{$\mathrm{pH}$} & \multicolumn{3}{|c|}{$\begin{array}{c}\text { Specific } \\
\text { conductance } \\
(\mathrm{S} / \mathrm{cm})\end{array}$} & \multicolumn{3}{|c|}{$\begin{array}{l}\text { Dissolved } \\
\text { solids } \\
\text { (mg/L) }\end{array}$} & \multicolumn{3}{|c|}{$\begin{array}{l}\text { Fluoride, } \\
\text { dissolved } \\
\text { (mg/L) }\end{array}$} & \multicolumn{3}{|c|}{$\begin{array}{l}\text { Arsenic, } \\
\text { dissolved } \\
(\mathrm{mg} / \mathrm{L})\end{array}$} \\
\hline & $\mathbf{N}$ & $\mathbf{R}$ & Mn/Md & $\mathbf{N}$ & $\mathbf{R}$ & Mn/Md & $\mathbf{N}$ & $\mathbf{R}$ & Mn/Md & $\mathbf{N}$ & $\mathbf{R}$ & Mn/Md & $\mathbf{N}$ & $\mathbf{R}$ & $\mathbf{M n} / \mathbf{M d}$ \\
\hline Wells & 383 & $\begin{array}{l}6.7- \\
8.9\end{array}$ & $\begin{array}{l}7.40 / \\
7.40\end{array}$ & 472 & $\begin{array}{c}55- \\
25,000\end{array}$ & $\begin{array}{l}1,165 / \\
750\end{array}$ & 197 & $\begin{array}{c}63- \\
97,700\end{array}$ & $\begin{array}{l}1,241 / \\
482\end{array}$ & 339 & $0-4$ & $\begin{array}{l}0.57 / \\
0.35\end{array}$ & 138 & $\begin{array}{c}.001- \\
.22\end{array}$ & $\begin{array}{c}.023 / \\
0.11\end{array}$ \\
\hline Springs & 89 & $\begin{array}{c}6.34- \\
8.20\end{array}$ & $\begin{array}{l}7.34 / \\
7.36\end{array}$ & 110 & $\begin{array}{c}25- \\
4,660\end{array}$ & $\begin{array}{l}782 / \\
695\end{array}$ & 97 & $\begin{array}{c}14- \\
3,230\end{array}$ & $\begin{array}{l}517 / \\
400\end{array}$ & 87 & $\begin{array}{l}0- \\
6.8\end{array}$ & $\begin{array}{l}0.40 / \\
0.20\end{array}$ & 9 & $\begin{array}{c}.001- \\
1.4\end{array}$ & $\begin{array}{l}0.18 / \\
.008\end{array}$ \\
\hline Streamflow & 397 & $\begin{array}{l}5.58- \\
12.00\end{array}$ & $\begin{array}{l}8.08 / \\
8.20\end{array}$ & 406 & $\begin{array}{l}17- \\
800\end{array}$ & $\begin{array}{l}319 / \\
351\end{array}$ & 349 & $\begin{array}{l}40- \\
440\end{array}$ & $\begin{array}{l}349 / \\
197\end{array}$ & 323 & $\begin{array}{l}0- \\
3.3\end{array}$ & $\begin{array}{l}0.92 / \\
0.50\end{array}$ & 89 & $\begin{array}{c}.001- \\
.17\end{array}$ & $\begin{array}{c}.022 / \\
0.13\end{array}$ \\
\hline
\end{tabular}

\section{Water Quality}

Water quality within the study area is variable. Well water tends to have high concentrations of dissolved solids, and individual water samples from wells and springs have high concentrations of arsenic and fluoride (table 1). U.S. Environmental Protection Agency (USEPA) Primary and Secondary Drinking-Water Regulations include a range of 6.5 to 8.5 for $\mathrm{pH}$ and a maximum of 500 milligrams per liter $(\mathrm{mg} / \mathrm{L})$ for dissolved solids. Concentrations of fluoride greater than 4.0 $\mathrm{mg} / \mathrm{L}$ and of arsenic greater than 0.05 $\mathrm{mg} / \mathrm{L}$ exceed USEPA Maximum Contaminant Levels.

\section{Remaining Questions}

A number of questions are fundamental to understanding the hydrogeologic system of the Mogollon Rim area. These include:

1. What is the recharge area for springs and wells in the Paleozoic sedimentary rocks?

2. Where is the ground-water divide separating flow toward the rim from flow moving toward the Little Colorado River?

3 . What are the hydrogeologic characteristics of the Tertiary volcanic rocks that cap some areas of the rim?

4. What are the rates of ground-water flow from the recharge areas to springs and wells in the upper Paleozoic aquifers such as the Coconino Sandstone and Upper Supai Formation?

5. Is there significant leakage from the upper Paleozoic aquifers into underlying sedimentary rocks and granite?

6. How sensitive are the water-bearing zones within the Lower Supai Formation and the Naco Formation to variability in recharge? What are the hydrologic characteristics of these formation? What constitutes sustainable use in aquifers within the Lower Supai and Naco Formations?

7. What are the characteristics of the regional ground-water flow system? Which geologic formations are components of the regional ground-water flow system, where are the flow paths, and what is the availability of water from that system?

8. Is the Payson granite recharged significantly from overlying or adjacent aquifers or is it recharged only from precipitation? What constitutes sustainable use within the Payson granite?

9. What are the flow paths south of Payson into the alluvial valley of the Tonto Basin?

10. What are the hydrogeologic characteristics of the Precambrian rocks that form the Mazatzal Mountains and the Sierra Ancha south of Payson?

11. How is human use affecting the surface- and ground-water systems at present, and how will future use affect these systems in terms of water availability and quality?

12. How are precipitation, surfacewater flows, and ground-water flows linked or partitioned throughout the hydrogeologic system?

\section{Possible Approaches}

The first year of the USGS study mainly involved the collection and compilation of existing data and the development of a hydrogeologic data base. These aspects of the study are expected to continue throughout the life of the project, however; the identification of data needs, collection of new data, and evaluation, synthesis, and analysis of data will become increasingly important as the project continues. Some of the approaches that may be used to answer the questions above and to develop conceptual and interpretive models of the hydrogeologic system in the study area include:

1. Synthesis and interpretation of existing geologic mapping to develop a preliminary three-dimensional geologic framework of the study area.

2. Analysis of the spatial relations among streams, springs, wells, and geologic features, including unit thickness, lithology, and dip, and structural characteristics including faults, fractures, and joints.

3. Analysis of the spatial variability in aquifer characteristics and the relation of such characteristics to geologic features.
4. Analysis of temporal relations among various components of the hydrologic system including precipitation, streamflow, spring discharge, and groundwater levels using new and available data.

5. Hydrochemical analyses to determine ground-water flow paths and residence times of ground-water within different parts of the hydrogeologic system.

6. Integration of geologic and hydrologic information to develop conceptual and predictive models of the regional hydrogeologic system.

7. Sensitivity analysis to identify those components of the hydrogeologic system that exert the greatest control over regional ground-water flow to aid in optimizing the collection of new data.

8. Development of a predictive model of regional ground-water flow to examine the effects of different waterresources development scenarios on the hydrologic system.

\section{—John T.C. Parker and Marilyn E. Flynn}

\section{References}

Feth, J.H., and Hem, J.D., 1963, Reconnaissance of headwater springs in the Gila River drainage basin, Arizona, U.S. Geological Survey Water-Supply Paper, 1619-H, p. H1-H54.

Mayer, L., 1978, Evolution of the Mogollon Rim in central Arizona: Tectonophysics, v. 61, p. 49-62.

Richards, A.M., 1987, Gravity analysis of the Tonto and Payson basins, central Arizona: Flagstaff, Arizona, Northern Arizona University, Master's thesis, $162 \mathrm{p}$.

Southwest Ground-water Consultants, Inc. (SGC), 1998, Long-term management program of the town of Payson's water resources: Phoenix, Arizona, Southwest Ground-water Consultants, Inc., Report for Town of Payson, 61 p. + appendices.

Weir, G.W., and Beard, L.S., 1997, Preliminary geologic map of the Strawberry quadrangle, Yavapai, Gila, and Coconino Counties, Arizona: U.S. Geological Survey Open-File Report, 94-0265, 1 sheet.

Weisman, M.K., and Weir, G.W., 1990, Geologic map of the Pine 7.5-minute quadrangle, Coconino and Gila Counties, Arizona: U.S. Geological Survey Miscellaneous Field Studies Map, MF-2123, 1 sheet.

Wilson, E.D., Moore, R.T, and Peirce, H.W., 1959, Geologic map of Gila County, Arizona, Tucson, Arizona Bureau of Mines, 1 sheet.

For further information, contact: John Parker

U.S. Geological Survey, WRD

520 North Park Avenue, Suite 221

Tucson, Arizona 85719-5035

E-mail: jtparker@usgs.gov or visit home page http://az.water.usgs.gov 